\title{
Recommended: Charlotte Perkins Gilman
}

\author{
Joyce Kinkead
}

Move over Gloria Steinem, Betty Friedan, Kate Millet. Charlotte Perkins Gilman is back. Actually, Gilman has been with us for a long time, just lying low until the time came when she was needed again. Although some readers may be saying "Charlotte who?" Gilman was a household word in the first part of this century, an early feminist whose works were not recognized as feminist writings until the 1970s. Gilman, however, would not have used the word feminist to describe herself; she was, instead, a humanist-concerned with the equality of both men and women. And this is the theme which dominates all of her writing-both fiction and nonfiction.

Born in 1860, the great-niece of Harriet Beecher Stowe and Henry Ward Beecher, Gilman grew up in a difficult situation, having a loveless relationship with her mother, her father having deserted them early on. The result was an unhappy childhood, one that helped form Gilman's ideas on marriage and the home, ideas which she wrote about extensively. A serious young woman, she wrote in her diary at seventeen, "Am going to try hard this winter to see if I cannot enjoy myself like other people," a reflection she noted in her autobiography, The Living of Charlotte Perkins Gilman (New York: Harper \& Row, 1963, first published in 1935). By 21, she was "self-supporting...., a necessary base for freedom." However, that freedom was cut short by her marriage to Charles Walter Stetson in 1884, a marriage that brought her to the brink of insanity and served as the basis for her most famous piece of fiction, "The Yellow Wallpaper" (Old Westbury, New York: The Feminist Press, 1973, first published in 1899). "The Yellow Wallpaper" duplicates Gilman's battles with depression. In the story, the narrator-a wife and a mother-has been prescribed the "rest cure" for her melancholy. Taken to the country by her husband John, who is a doctor, the narrator wants to work and write, but the medical advice she receives from him dictates that she receive total rest, a condition that can only result from a total emptiness of mind. Her husband patronizes her, she attempts to rebel against the rest cure, sensing it is making her more ill, but her husband and housekeeper insist that doctor knows best. Despite her pleas to move from the supposedly restful country, he insists they stay. She is kept in her bedroom with its strangely patterned yellow wallpaper. She describes the "lame uncertain curves" that suddenly "commit suicide-destroy themselves in unheard-of contradictions." In her confinement, she begins to envision a woman caught by the design of bars in the wallpaper, a symbol of her own imprisonment. As the days go by, she descends into madness until her husband returns home one day to find her "creeping" around the bedroom. The story was refused publication several times as editors rejected it for being too depressing, not uplifting. Until its reappearance in 1973 , it was looked at as a chilling horror story rather than an indictment of male-female relationships.

In her own time though, Gilman was better known for her non-fiction. Although a frequent speaker in women's suffrage groups, she stressed the importance of looking beyond the vote. Her satiric verse, In This Our World (1893), espoused these beliefs. In her own world, she enjoyed her solitude following her divorce, turning over her daughter to her former husband and new wife to rear, a move that branded her as an unnatural mother. Women and Economics promoted the advantages of such a move in its comment on the role of women in society. This witty, satiric book, focused on "the common humanity" of both sexes and attacked the socio-economic system that forced women into domestic slavery. She compares women to both horses and cows:

The labor of women in the house, certainly, enables men to produce more wealth than they otherwise could; and in this way women are economic factors in society. But so are horses. The labor of horses enables men to produce more wealth than they otherwise could. The horse is an economic factor in society. But the horse is not economically independent, nor is the woman.

The wild cow is a female. She has healthy calves, and milk enough for them. And that is all the femininity she needs. Otherwise than that she is bovine 
rather than feminine. She is a light, strong, swift, sinewy creature, able to run, jump, and fight, if necessary. We, for economic uses, have artificially developed the cow's capacity for producing milk. She has become a walking milk-machine, bred and tended to that express end, her value measured in quarts.

In short, at the turn of the century, a woman's livelihood depended on "a small gold ring," but Gilman preferred to emphasize the potential of women outside the home. She noted that, ironically, Victorian women were over-sexed because of the limited options open to them and argued that to deprive women of options was to make the world a poorer place to live. In spite of giving up her daughter, she was a believer in home and family, though she advocated emancipated motherhood with nursery schools and kindergartens for children. In The Man-Made World (Johnson Reprint, 1971, first published in 1911), she traces the development of this Victorian woman through social conditioning. Her Concerning Children (1900) offered ideas for rearing and educating children while in The Home (1902), she supported the "kitchenless home," cutting the chain which bound most women by substituting ready-made dinners, professional cooking staffs for centralized housing, and a utopian community hotel. Two years later, Human Work (1904) looked at the benefits of work for both males and females; in it, she argued that it was possible to have both work and marriage.

From 1909 to 1916, Gilman undertook the task of editing and writing all of the copy for her monthly magazine, The Forerunner, which averaged 21,000 words per month. The fiction she produced for these issues was written to make a point, but the stories are interesting and even relevant to our times as the female characters try to cope with their world and to come to some understanding of their roles in that world. Some of the best of these stories-along with other representative fictional work of Gilman'scan be found in The Charlotte Perkins Gilman Reader (New York: Pantheon, 1980).

The Reader also contains several condensed novels. The Crux (1911) introduces the problem of venereal disease at the turn of the century. The heroine, Vivian, is about to marry Morton. Even though Morton and his doctor both know he has syphillis, neither of them will stop the marriage because they want to save the man's honor.

A year later, another novel, What Diantha Did (1912), was published after being serialized in The Forerunner. What Diantha did was to follow a non-traditional path and capitalize on her domestic skills by setting up an efficient household and later a hotel. She escapes from a home where her mother hates housework and her father hates his job, gives up her hated teaching job, and leaves her fiance who runs the family store-which he hates. Eventually, they do marry, but her husband has a difficult time coping with Diantha's working outside the home. They only become fully happy when he at last begins "to grasp the nature and importance" of her work.

Gilman's next novel, Benigna Machiavelli (1914), is a survival book for the modern girl whose education includes brushes with various villains and glimpses of both traditional and non-traditional malefemale relationships. A later unpublished detective novel, Unpunished, still hammers the same theme: the dependency of women on men. In this case, the man is a sadist who torments his crippled sister-in-law; however, here, he becomes the victim in the murder mystery.

The final three selections in The Reader are excerpts from her utopian novels, a more common forum for Gilman. Inspired by Edward Bellamy's Looking Backward, she wrote Moving the Mountain (1911), Herland (New York: Pantheon, 1979, first published in 1915), and With Her in Ourland (1916). The first is set in the United States in 1940, twenty years after the American people voted in socialism. The world is changed by "no other change than a change in mind, the mere awakening of people, especially the women, to existing possibilities." The house has lost its chores, and people settle into their "worldwork," collectively rearing the children. Herland describes a society of women into which three men blunder, only to be converted to the society's humanistic ideas. In this society, women are freed from male sexuality, having developed the ability to reproduce parthenogenically. In the sequel, With Her in Ourland, Ellador discovers war, waste, corruption, poverty, and ignorance of women in a traditional society.

Gilman's focus-attainment of full equality for women-echoes through all of her writing. Interest in her writing has revived not only because of her subject but also because her lively style and wit allow the reader to gain a historical perspective on woman's role. Her masterpiece, "The Yellow Wallpaper," is the most accessible and the most worthwhile for the classroom. In it, as in all of her work, there is evidence of her vitality and commitment. Just before her death in 1935 , she wrote in her autobiography:

My life is in Humanity-and that goes on. My contentment is in God-and That goes on. The Social Consciousness, fully accepted, automatically eliminates both selfishness and pride.

The one predominant duty is to find one's work and do it, and I have striven mightily at that.

The religion, the philosophy, set up so early, have seen me through.

Fifty years after her death, her work continues to go on.

Joyce Kinkead teaches at Utah State University. 